\title{
ОСОБЛИВОСТІ ПРО- Й АНТИОКСИДАНТНОЇ СИСТЕМ ТА ОБМІНУ СПОЛУЧНОЇ ТКАНИНИ В ПАЦІЕНТІВ ІЗ ПІСЛЯОПЕРАЦІЙНОЮ ВЕНТРАЛЬНОЮ ГРИЖЕЮ ЗА УМОВ КОМОРБДНОСТІ
}

Вступ. Проблема рецидивів післяопераційних вентральних гриж (ПОВГ) продовжує залишатись однією з актуальних. Використання сітчастих імплантатів у лікуванні ПОВГ значно знизило кількість ускладнень та рецидивів, проте їх частота і надалі висока.

Мета дослідження - вивчити особливості про- й антиоксидантного статусу та обміну сполучної тканини в пацієнтів з ПОВГ за умов коморбідності залежно від типу поліпропіленової сітки і в комбінації іï з PRF мембраною.

Методи дослідження. Обстежено 276 пацієнтів з ПОВГ (основна група та група порівняння), яких було розділено за типом імплантованої поліпропіленової сітки під час виконання операційного втручання, з метою оцінки стану метаболізму сполучної тканини.

Результати й обговорення. Було доведено, що застосування “легкоі" сітки “Омега-2" в комбінації з PRF мембраною в хірургічному лікуванні пацієнтів з ПОВГ за умов коморбідності краще сприяє поліпшенню показників обміну сполучної тканини і прооксидантно-антиоксидантного статусу, ніж при використанні "легких" та "важких" сіток.

Висновок. Використання в хірургічному лікуванні хворих на ПОВГ за умов коморбідності “легкоі" сітки "Омега-2" в комбінації з PRF мембраною сприяє кращій позитивній динаміці про- й антиоксидантного статусу за дослідженими біохімічними показниками, ніж при застосуванні “легких" та "важких" сіток $(p<0,05)$, а також призводить до найбільш вагомого поліпшення показників метаболізму сполучної тканини за дослідженими параметрами $(p<0,05)$ порівняно з використанням “легких" та "важких" сіток.

КЛЮЧОВІ СЛОВА: післяопераційні вентральні грижі; поліпропіленова сітка; PRF мембрана; про- й антиоксидантна системи; дисплазія сполучної тканини.

ВСТУП. Післяопераційні вентральні грижі (ПОВГ) становлять 22,9 \% від загальної кількості гриж живота. Частота ПОВГ, незважаючи на широке впровадження в хірургію органів черевної порожнини сучасних малоінвазивних і лапароскопічних технологій, не зменшується, що зумовлено зростанням кількості лапаротомій в останні роки та, відповідно, післяопераційних ускладнень. Упровадження в хірургічне лікування ПОВГ сітчастих імплантатів значно знизило частоту післяопераційних ускладнень, тому використання поліпропіленових сіток у хірургії ПОВГ є беззаперечним. Проте їх застосування супроводжується вираженою запальною реакцією в ділянці імплантації, сприяє формуванню грубої сполучнотканинної капсули та, як наслідок, призводить до зморщування сітки. Невирішеним залишається питання щодо післяопераційних ексудативних ускладнень, які спричиняють тяжкий післяопераційний перебіг [1-3].

(c) В. І. П'ятночка, Н. А. Мельник, 2018.
Основними причинами рецидивів після алогерніопластики є необґрунтований вибір методу пластики і типу поліпропіленової сітки без індивідуалізованого підходу до кожного окремо взятого пацієнта з урахуванням коморбідної патології, технічні помилки виконання операційного втручання, інфекційні ускладнення, змінений метаболізм колагену, що проявляється недисеренційованою дисплазією сполучної тканини. Встановлено, що низьке співвідношення між колагеном I та III типів послаблює механічну міцність м'язів та апоневрозу за межами фріксованого сітчастого імплантата. Це визначається срормуванням стоншених ділянок, а згодом і десектів передньої черевної стінки. Тому діагностика синдрому недифреренційованої дисплазії сполучної тканини є важливою для прогнозування та попередження можливості виникнення післяопераційних ускладнень [4-6].

При діагностиці недифреренційованоі дисплазії сполучної тканини велике допоміжне значен- 
ня мають біохімічні методи дослідження, що дозволяють оцінити стан обміну сполучної тканини, уточнити діагноз, спрогнозувати перебіг захворювання. Сполучна тканина та її позаклітинний матрикс - складна багатокомпонентна система. У біохімічному аспекті високий ступінь організованості й упорядкованості міжклітинного матриксу виражається специфрічними кількісними співвідношеннями біополімерів, які його утворюють. Будь-які відхилення від цих специфрічних співвідношень можуть спричинити порушення як структури, так і фрункції сполучної тканини.

Одним 3 основних показників метаболізму колагену є вміст оксипроліну (ОП). Оксипролін (похідне проліну) - одна з головних амінокислот колагену, що є маркером його катаболізму. Тому у хворих з порушеним метаболізмом сполучної тканини збільшуються екскреція ОП із сечею, вміст його вільної фрракції і зменшується вміст зв'язаної фрракції. При цьому вираження біохімічних змін корелює з тяжкістю патологічного процесу. Більш повну картину про обмін сполучної тканини можна отримати при визначенні глікозаміногліканів (ГАГ), які показують ступінь катаболізму міжклітинної речовини сполучної тканини

Важливими біохімічними механізмами травматичного ураження, зокрема післяопераційного, є зміни прооксидантно-антиоксидантного балансу. Він характеризується оптимальним співвідношенням між концентрацією продуктів пероксидного окиснення ліпідів (ПОЛ) та рівнем несрерментних і фрерментних антиоксидантів у біологічних середовищах організму за умов фрізіологічної норми, що підтримує перебіг основних метаболічних процесів.

Окисно-відновні процеси - дуже важлива ланка метаболічного ланцюга, яка необхідна для оптимального енергозабезпечення, доставки та утилізації кисню в тканинах. За нормальних умов процеси окиснення та відновлення збалансовані [7]. У разі патологічного процесу, виснаження депо антиоксидантів, нераціонального харчування, стресу та інших негативних впливів виникає окисний стрес, для якого характерним є порушення прооксидантного й антиоксидантного балансу з переважанням першого і розвитком оксидативних ушкоджень. Відомо, що антиоксидантна система (АОС) нівелює патологічні ефекти вільних радикалів, попереджуючи їх утворення, забезпечуючи їх зв'язування та модифікацію, стимулює руйнування пероксидів [8, 9]. Інтенсифрікація ПОЛ поєднується зі змінами антирадикального захисту, що проявляється дисрегуляцією в системі пероксидації - антиоксидації, причому вираження цього дисбалансу залежить від ступеня тяжкості цього захворювання, супутньої патології, віку. Тому вивчення стану про- й антиоксидантного статусу у хворих на післяопераційні вентральні грижі за умов коморбідності $\epsilon$ важливим та актуальним.

Мета дослідження - вивчити особливості про- й антиоксидантного статусу та обміну сполучної тканини в пацієнтів з ПОВГ за умов коморбідності залежно від типу поліпропіленової сітки і в комбінації її з PRF мембраною.

МЕТОДИ ДОСЛІДЖЕННЯ. Робота базУється на дослідженні 276 пацієнтів, оперованих у клініці хірургії Навчально-наукового інституту післядипломної освіти Тернопільського державного медичного університету імені І. Я. Горбачевського на базі хірургічного відділення КНП "Тернопільська комунальна міська лікарня № 2" у період з 2011 до 2017 р. У всіх хворих були наявні лише ПОВГ типу M1-2W1-2R1-2 за класифрікацією J. P. Chevrel, A. M. Rath (SWR classification, 1999), яку використовували з метою отримання статистично достовірних результатів. Усіх обстежуваних пацієнтів поділили на дві групи за наявністю коморбідної патології залежно від величини індексу коморбідності Charlson: основну групу (пацієнти віком понад 60 років) та групу порівняння (пацієнти віком до 60 років) [10]. Усім хворим виконано ретромускулярну пластику з імплантацією “легкої” поліпропіленової сітки фрірми "УКРТЕХМЕД” "Омега-2" (із пи-

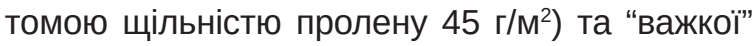
сітки "Омега-4" (із питомою щільністю пролену 115 г/м²), а також "легкої" сітки "Омега-2" у комбінації з PRF мембраною (Platelet Rich Fibrin збагачений тромбоцитами фрібрин).

Діагноз ПОВГ вериорікували відповідно до класисрікації ПОВГ Європейської асоціації хірургів-герніологів (EHS classification, Гент, Бельгія, 2009) [11].

Для оцінки стану метаболізму сполучної тканини визначали вміст у сироватці крові вільного ОП та екскрецію ГАГ у сечі.

Оксипролін - основна амінокислота, яка міститься в колагені. Нормативні величини біохімічних показників отримано при обстеженні 20 практично здорових осіб (контрольна група), яких було зіставлено за віком і статтю з обстежуваними 106 хворими на ПОВГ. Цей показник у нормі становив $(11,6 \pm 0,9)$ мкмоль/л. Метаболізм ОП досліджували за колориметричним методом L. Bergman тa R. Loxley в модифрікації M. А. Осадчук і Т. П. Кузнєцової. Вміст кріоглобулінів у сироватці крові визначали за методикою Н. А. Константинової та А. Ю. Кірсанова (1989), принцип якої полягає у встановленні різниці оптичної щільності розчину сироватки крові у веронал-ме- 
диналовому буфері $(\mathrm{pH}=8,6)$ при температурі 4 i $37^{\circ} \mathrm{C}$ [12].

Вміст ГАГ у сечі визначали за методом Діше в модифрікації П. Н. Шараєва, що базується на колориметричному визначенні уронових кислот 3 карбазолом [13]. Нормою вважали $(39,3 \pm 0,9)$ мкмоль/л.

Про стан ПОЛ та АОС до й після лікування судили за рівнями малонового альдегіду (МА), супероксиддисмутази (СОД) і каталази крові.

Активність СОД визначали за її здатністю конкурувати з нітротетразолієм синім за супероксидні аніони, які утворюються внаслідок аеробної взаємодії відновленої форми НАДН та френазинметасульфрату [14]. Кількість фрерменту визначали спектрометричним методом. Нормою вважали $(62,15 \pm 2,82)$ ум. од.

Рівень каталазної активності визначали за здатністю пероксиду водню утворювати 3 молібдатом амонієм стійкий забарвлений комплекс, інтенсивність забарвлення якого залежить від каталазної активності в пробі [15]. Норма каталазної активності в крові становила $(17,48 \pm 0,87) \%$.

Рівень МА визначали за методом В. М. Орєховича в модисрікації Л. І. Андреєвої з тіобарбітуратовою кислотою відповідно. Активність МА у плазмі крові виражали в мкмоль/л [16]. Норма становила $(2,810 \pm 0,085)$ мкмоль/л.

Статистичну обробку отриманих даних виконували на персональному комп'ютері з використанням стандартних пакетів програм Microsoft Excel та за допомогою комп'ютерної програми Statistica for Windows версії 6.0 (Stat Soft inc.,
США) із застосуванням непараметричних методів: для порівняння двох незалежних вибірок використовували U-критерій Манна - Уїтні, а 3 метою оцінки динамічних змін усередині груп критерій Вілкоксона (W-критерій). Для кожної досліджуваної групи вираховували середню арисрметичну величину (М), середньоквадратичне відхилення (q) та похибку середньої арифрметичної величини (m). Середні величини представлено як $\mathrm{M} \pm \mathrm{m}$.

РЕЗУЛЬТАТИЙ ОБГОВОРЕННЯ. ПрИ ДОСЛідженні стану показників ПОЛ до лікування у хворих на ПОВГ виявлено, що рівень МА як маркера інтенсифрікації ПОЛ був достовірно вищим в основній та групі порівняння порівняно 3 контрольною (табл. 1). Після проведеного операційного втручання з імплантацією "важкої" і “легкої" поліпропіленових сіток рівень МА в групі порівняння та основній дещо знизився - на 5,65 і 5,69 \% та 4,76 і 4,07 \% відповідно, що вказувало на певне пригнічення утворення кінцевих продуктів ліпідної пероксидації за рахунок посилення утворення початкових продуктів ПОЛ (після операційного втручання). Однак ці зміни були не значні та статистично не значимі $(p>0,05)$. У день виписування в пацієнтів, яким імплантували "легку" сітку, відмічено кращу, ніж у хворих з "важкою" сіткою, динаміку рівня МА: в основній групі він зменшувався на 46,10\% проти $26,10 \%$, а в групі порівняння - на 33,98 \% проти 17,78 \% (p<0,05). Щодо пацієнтів з імплантованою "легкою" сіткою в комбінації з PRF мембраною, то рівень МА в них знижувався най-

Таблиця 1 - Динаміка рівня малонового альдегіду (мкмольл) у хворих на післяопераційні вентральні грижі в основній та групі порівняння залежно від типу поліпропіленової сітки (M士m)

\begin{tabular}{|c|c|c|c|c|c|c|}
\hline \multirow{3}{*}{$\begin{array}{c}\text { День } \\
\text { спостереження }\end{array}$} & \multicolumn{6}{|c|}{ Група } \\
\hline & \multicolumn{2}{|c|}{ порівняння } & \multicolumn{3}{|c|}{ основна } & \multirow[b]{2}{*}{$\begin{array}{c}\text { контрольна } \\
\quad(\mathrm{n}=20)\end{array}$} \\
\hline & $\begin{array}{c}\text { "важка" сітка } \\
(n=55)\end{array}$ & $\begin{array}{l}\text { “легка" сітка } \\
(n=56)\end{array}$ & $\begin{array}{c}\text { “важка" сітка } \\
(n=55)\end{array}$ & $\begin{array}{l}\text { “легка" сітка } \\
\text { (n=56) }\end{array}$ & $\begin{array}{c}\text { "легка" сітка+ } \\
\text { PRF мембрана } \\
(\mathrm{n}=54)\end{array}$ & \\
\hline До лікування & $6,19 \pm 0,13$ & $6,15 \pm 0,04$ & $8,20 \pm 0,13$ & $8,10 \pm 0,05$ & $8,20 \pm 0,05$ & \multirow[t]{3}{*}{$2,18 \pm 0,10$} \\
\hline $\begin{array}{l}\text { 1-й день після } \\
\text { лікування }\end{array}$ & $\begin{array}{c}5,84 \pm 0,04 \\
\# p<0,05 \\
* p>0,05\end{array}$ & $\begin{array}{c}5,80 \pm 0,24 \\
\# p<0,05 \\
* p>0,05\end{array}$ & $\begin{array}{l}7,81 \pm 0,26 \\
{ }^{\#} p<0,05 \\
* p>0,05\end{array}$ & $\begin{array}{c}7,77 \pm 0,20 \\
{ }^{*} p<0,05 \\
* p>0,05\end{array}$ & $\begin{array}{c}7,63 \pm 0,29 \\
{ }^{*} p<0,05 \\
* p>0,05\end{array}$ & \\
\hline $\begin{array}{l}\text { День випису- } \\
\text { вання }\end{array}$ & $\begin{array}{c}5,09 \pm 0,09 \\
{ }^{\#} p<0,05 \\
{ }^{*} p<0,05\end{array}$ & $\begin{array}{c}4,06 \pm 0,04 \\
{ }^{\#} p<0,05 \\
{ }^{*} p<0,05 \\
{ }^{* *} p<0,05\end{array}$ & $\begin{array}{c}6,06 \pm 0,08 \\
{ }^{\#} p<0,05 \\
{ }^{*} p<0,05 \\
{ }^{\# \#} p<0,05\end{array}$ & $\begin{array}{c}4,37 \pm 0,04 \\
{ }^{\#} p<0,05 \\
{ }^{*} p<0,05 \\
{ }^{\#} p<0,05 \\
{ }^{* *} p<0,05\end{array}$ & $\begin{array}{c}3,20 \pm 0,09 \\
\# p<0,05 \\
* p<0,05 \\
\# p<0,05 \\
* * p<0,05 \\
* * * p<0,05\end{array}$ & \\
\hline
\end{tabular}

Примітки. Тут і в таблиці 2:

1. \# - достовірність різниці стосовно таких показників контрольної групи.

2. * - достовірність різниці стосовно таких показників своєї групи до лікування.

3. ** - достовірність різниці стосовно таких показників у пацієнтів з "важкою" сіткою.

4. \# - достовірність різниці стосовно таких показників групи порівняння.

5. *** - достовірність різниці стосовно таких показників у пацієнтів з “легкою" сіткою. 
більше (на 6,95 \% на 1-й день після операційного втручання та на 60,98 \% у день виписування) і був статистично значимо вищим порівняно 3 таким показником у хворих, яким імплантували лише "легку" сітку ( $p<0,05)$.

На 1-й день після операційного втручання відмічали зниження антиоксидантного захисту, зокрема при імплантації "легкої" і "важкої" сіток рівень СОД у пацієнтів основної та групи порівняння зменшувався на 34,40 і 35,02 \% та 30,35 і $28,80$ \% відповідно ( $<<0,05)$ (табл. 2). У хворих 3 імплантованою "легкою" сіткою в комбінації 3 PRF мембраною на 1-й день після операції рівень СОД також знижувався - на 30,78 \% порівняно з таким показником до лікування. Це свідчило про послаблення антиоксидантного захисту на найбільш критичному етапі післяопераційного періоду. В день виписування статистично значимо кращу динаміку СОД відмічали у хворих з імплантованою "легкою" сіткою порівняно з пацієнтами з "важкою" сіткою: рівень СОД підвищувався на 41,87 \% проти 24,07 \% в основній групі та на 32,63 \% проти 13,83 \% у групі порівняння $(p<0,05)$. Однак найбільш значне статистично значиме зростання рівня СОДу день виписування відзначали в пацієнтів з імплантованою "легкою" сіткою в комбінації з PRF мемб- раною - на 69,01 \% порівняно з таким показником до лікування.

Рівень каталази в плазмі крові після лікування змінювався аналогічно рівню СОД. На 1-й день після проведеного лікування рівень каталази при імплантації “легкої" і "важкої” поліпропіленових сіток у пацієнтів основної та групи порівняння знижувався на 55,84 і 55,58 \% та $61,91$ і 62,40 \% відповідно ( $<<0,05)$. У хворих 3 імплантованою “легкою" сіткою в комбінації 3 PRF мембраною рівень каталази на 1-й день після операції також зменшувався - на 55,96 \% порівняно $з$ таким показником до лікування, що свідчило про виснаження адаптаційних ресурсів АОС. У день виписування відмічали більш вагому позитивну динаміку рівня каталази в крові пацієнтів $з$ імплантованою “легкою" сіткою: в основній групі він підвищувався на 67,06 \% порівняно з таким показником на 1-й день після операційного втручання, а в групі порівняння - на 61,26 \%. Дещо менший приріст рівня каталази в день виписування відзначали у хворих з імплантованою "важкою" сіткою порівняно з таким показником на 1-й день після операції: в основній групі приріст становив 32,10\%, а в групі порівняння - 25,91 \% (p<0,05). Однак найбільший приріст рівня каталази в день виписування

Таблиця 2 - Динаміка показників антиоксидантної системи у хворих на післяопераційні вентральні грижі в основній та групі порівняння залежно від типу поліпропіленової сітки

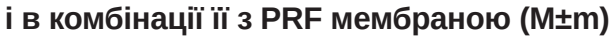

\begin{tabular}{|c|c|c|c|c|c|c|}
\hline \multirow{3}{*}{$\begin{array}{c}\text { Показник } \\
\text { антиоксидантної } \\
\text { системи, } \\
\text { день } \\
\text { спостереження }\end{array}$} & \multicolumn{6}{|c|}{ Група } \\
\hline & \multicolumn{2}{|c|}{ порівняння } & \multicolumn{3}{|c|}{ основна } & \multirow[b]{2}{*}{$\begin{array}{c}\text { контрольна } \\
(\mathrm{n}=20)\end{array}$} \\
\hline & $\begin{array}{c}\text { "важка" } \\
\text { сітка } \\
(n=55)\end{array}$ & $\begin{array}{c}\text { “легка" } \\
\text { сітка } \\
(n=56)\end{array}$ & $\begin{array}{c}\text { "важка" } \\
\text { сітка } \\
(n=55)\end{array}$ & $\begin{array}{c}\text { “легка" } \\
\text { сітка } \\
(\mathrm{n}=56)\end{array}$ & $\begin{array}{c}\text { “легка" сітка+ } \\
\text { PRF мембрана } \\
(n=54)\end{array}$ & \\
\hline $\begin{array}{l}\text { СОД, ум. од., } \\
\text { до лікування }\end{array}$ & $39,17 \pm 0,53$ & $39,53 \pm 0,36$ & $33,32 \pm 0,46$ & $33,34 \pm 0,39$ & $33,33 \pm 0,42$ & \multirow[t]{3}{*}{$62,15 \pm 2,85$} \\
\hline $\begin{array}{l}\text { СОД, ум. од., } \\
\text { на 1-й день } \\
\text { після лікування }\end{array}$ & $\begin{array}{c}27,89 \pm 0,38 \\
{ }^{\#} p<0,05 \\
{ }^{*} p<0,05\end{array}$ & $\begin{array}{c}27,74 \pm 0,34 \\
{ }^{*} p<0,05 \\
{ }^{*} p<0,05\end{array}$ & $\begin{array}{c}21,65 \pm 0,44 \\
{ }^{\#} p<0,05 \\
{ }^{*} p<0,05\end{array}$ & $\begin{array}{l}21,87 \pm 0,47 \\
{ }^{\#} p<0,05 \\
{ }^{*} p<0,05\end{array}$ & $\begin{array}{l}23,07 \pm 0,47 \\
{ }^{\#} p<0,05 \\
{ }^{*} p<0,05\end{array}$ & \\
\hline $\begin{array}{l}\text { СОД, ум. од., } \\
\text { у день випису- } \\
\text { вання }\end{array}$ & $\begin{array}{c}44,59 \pm 0,43 \\
{ }^{\#} p<0,05 \\
{ }^{*} p<0,05\end{array}$ & $\begin{array}{c}52,43 \pm 0,43 \\
{ }^{*} p<0,05 \\
{ }^{*} p<0,05 \\
* * p<0,05\end{array}$ & $\begin{array}{l}41,34 \pm 0,45 \\
{ }^{\#} p<0,05 \\
{ }^{*} p<0,05 \\
{ }^{*} p<0,05 \\
{ }^{\#} p<0,05\end{array}$ & $\begin{array}{l}47,30 \pm 0,37 \\
{ }^{\#} p<0,05 \\
{ }^{*} p<0,05 \\
{ }^{\#} p<0,05 \\
{ }^{* *} p<0,05\end{array}$ & $\begin{array}{l}56,33 \pm 0,49 \\
{ }^{\# p} p<0,05 \\
{ }^{*} p<0,05 \\
{ }_{\#} p<0,05 \\
* * p<0,05 \\
* \star * p<0,05\end{array}$ & \\
\hline $\begin{array}{l}\text { Каталаза, \%, } \\
\text { до лікування }\end{array}$ & $56,54 \pm 0,50$ & $56,18 \pm 0,42$ & $61,14 \pm 0,54$ & $61,19 \pm 0,44$ & $61,20 \pm 0,32$ & \multirow[t]{3}{*}{$17,48 \pm 0,87$} \\
\hline $\begin{array}{l}\text { Каталаза, \%, } \\
\text { на 1-й день } \\
\text { після лікування }\end{array}$ & $\begin{array}{c}21,26 \pm 0,35 \\
{ }^{\#} p<0,05 \\
{ }^{*} p<0,05\end{array}$ & $\begin{array}{c}21,40 \pm 0,40 \\
{ }^{*} p<0,05 \\
{ }^{*} p<0,05\end{array}$ & $\begin{array}{c}27,16 \pm 0,47 \\
{ }^{\#} p<0,05 \\
{ }^{*} p<0,05\end{array}$ & $\begin{array}{c}27,02 \pm 0,46 \\
{ }^{\#} p<0,05 \\
{ }^{*} p<0,05\end{array}$ & $\begin{array}{c}26,95 \pm 0,32 \\
{ }^{\#} p<0,05 \\
{ }^{*} p<0,05\end{array}$ & \\
\hline $\begin{array}{l}\text { Каталаза, \%, } \\
\text { у день випису- } \\
\text { вання }\end{array}$ & $\begin{array}{c}26,77 \pm 0,36 \\
{ }^{\#} p<0,05 \\
{ }^{*} p<0,05\end{array}$ & $\begin{array}{c}34,51 \pm 0,43 \\
{ }^{*} p<0,05 \\
{ }^{*} p<0,05 \\
* * p<0,05\end{array}$ & $\begin{array}{c}35,88 \pm 0,37 \\
{ }^{\#} p<0,05 \\
{ }^{*} p<0,05 \\
{ }^{*} p<0,05 \\
{ }^{\#} p<0,05\end{array}$ & $\begin{array}{c}45,14 \pm 0,39 \\
{ }^{\#} p<0,05 \\
{ }^{*} p<0,05 \\
{ }^{\#} p<0,05 \\
{ }^{* *} p<0,05\end{array}$ & $\begin{array}{l}51,00 \pm 0,37 \\
{ }^{\# p}<<0,05 \\
{ }^{*} p<0,05 \\
\# p<0,05 \\
\star * p<0,05 \\
\star \star \star * p<0,05\end{array}$ & \\
\hline
\end{tabular}


спостерігали в пацієнтів 3 імплантованою "легкою" сіткою в комбінації з PRF мембраною: приріст становив 89,24 \% порівняно з даними до лікування і був статистично значимо вищим відносно такого показника у хворих з імплантованою “легкою” сіткою ( $<<0,05)$.

При дослідженні динаміки показників сполучної тканини у хворих на ПОВГ на 1-й день після операційного втручання відзначали деяке їх підвищення щодо таких показників до лікування (рис. 1). Так, зокрема, рівень сироваткового ОП у пацієнтів 3 імплантованими "важкою" та “легкою" сітками на 1-й день після операції статистично значимо зростав: в основній групі - на 25,88 і 25,77 \%, а в групі порівняння - на 24,76 та $23,86 \%(p<0,05)$. У день виписування рівень вільного ОП у сироватці крові хворих з імплантованою "легкою" сіткою більш значимо зменшувався відносно такого показника в пацієнтів 3 "важкою" сіткою: в основній групі - на 11,86 \%, а в групі порівняння - на 9,96 \%) (p<0,05). Однак найкращу позитивну динаміку щодо концентрації сироваткового ОП у день виписування відмічали в пацієнтів з імплантованою “легкою” сіткою в комбінації з PRF мембраною. Рівень ОП у цих хворих знижувався на 52,00 \% порівняно з вихідними даними до лікування і був статистично

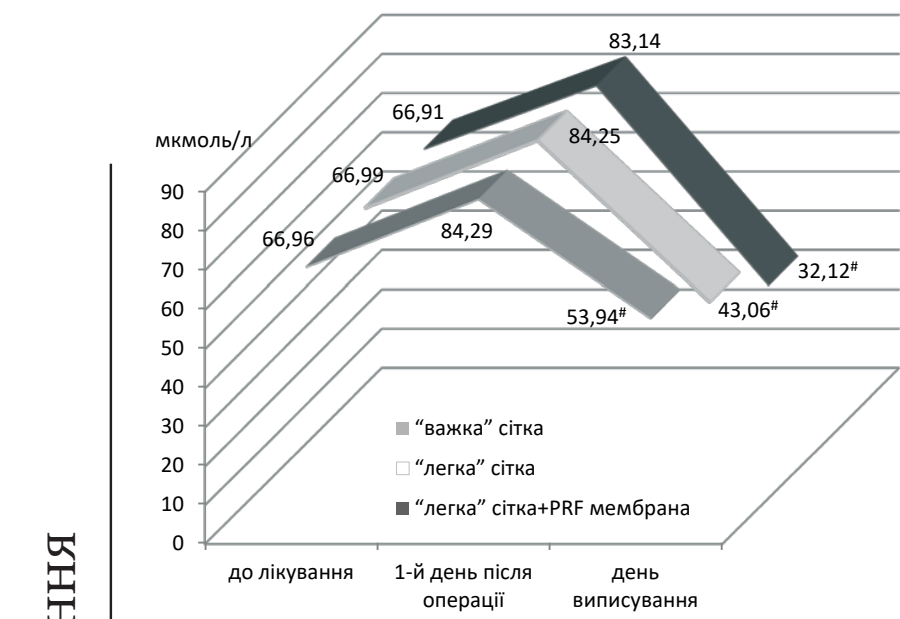

Рис. 1. Динаміка вмісту оксипроліну в основній групі хворих на післяопераційні вентральні грижі залежно від типу поліпропіленової сітки (" - достовірність різниці стосовно таких показників своєї групи до лікування).

ВИСНОВКИ. Використання в хірургічному лікуванні хворих на ПОВГ за умов коморбідності “легкої" сітки "Омега-2" в комбінації з PRF мембраною сприяє кращій позитивній динаміці про-й антиоксидантного статусу за дослідженими біохімічними показниками, ніж при застосуванні значимо вищим порівняно з таким показником у пацієнтів 3 імплантованою “легкою” сіткою $(p<0,05)$.

Концентрація ГАГ у сечі пацієнтів з ПОВГ у післяопераційний період змінювалася аналогічно концентрації сироваткового ОП (рис. 2). На 1-й день після операційного втручання у хворих з імплантованими "важкою" та "легкою" сітками спостерігали деяке зростання рівня ГАГ щодо такого показника до лікування: в основній групі він збільшувався на 23,15 і 23,28 \%, а в групі порівняння - на 23,95 та 25,01 \% відповідно. У пацієнтів 3 “легкою" сіткою в комбінації 3 PRF мембраною рівень ГАГ на 1-й день зростав на 22,42 \% відносно вихідних даних до лікування. У день виписування статистично значимо кращу динаміку концентрації ГАГ відмічали у хворих 3 імплантованою "легкою" сіткою порівняно 3 пацієнтами 3 "важкою" сіткою: рівень ГАГ збільшувався на 39,69 \% проти 218,0 \% в основній групі та на 24,97 \% проти 14,74 \% в групі порівняння $(p<0,05)$.

Однак найбільш значне статистично значиме зростання рівня ГАГ у день виписування відмічали в пацієнтів з імплантованою "легкою" сіткою в комбінації з PRF мембраною - на 60,97 \% порівняно з таким показником до лікування.

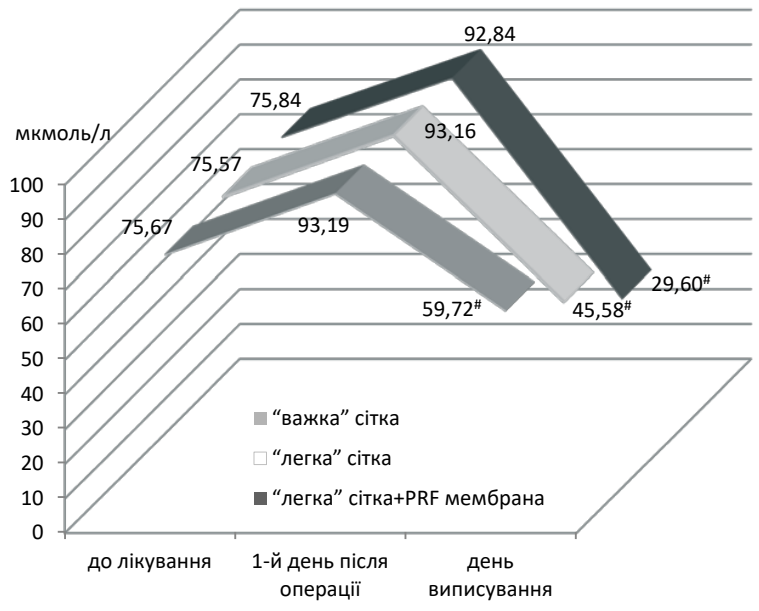

Рис. 2. Динаміка вмісту глікозаміногліканів в основній групі хворих на післяопераційні вентральні грижі залежно від типу поліпропіленової сітки (\# - достовірність різниці стосовно таких показників своєї групи до лікування).

"легких" та "важких" сіток (р<0,05), а також призводить до найбільш вагомого поліпшення показників метаболізму сполучної тканини за дослідженими параметрами ( $p<0,05)$ порівняно 3 використанням "легких" та "важких" сіток. 


\section{СПИСОК ЛІТЕРАТУРИ}

1. Білянський Л. С. Хірургічна тактика у хворих 3 гігантськими дефектами черевної стінки / Л. С. Білянський, І. М. Тодуров, С. В. Косюхно // Укр. журн. хірурriï. - 2015. - № 2 (11). - С. 19-24.

2. Петров Д. Ю. Дифрференцированный подход к выбору метода аллогерниопластики / Д. Ю. Петров, А. И. Ковалев, А. В. Смирнов // Актуальные вопросы герниологии : материалы конф. - М., 2013. - С. 119121.

3. Фелештинський Я. П. Сучасні способи хірургічного лікування післяопераційних гриж живота / Я. П. Фелештинський // Здоров'я України. - 2012. C. 24-27.

4. Брек О. О. Морфометричні та гістологічні зміни тканин у хворих після операцій з приводу післяопераційних гриж черевної порожнини / О. О. Брек // Клініч. хірургія. - 2015. - № 5. - С. 27-30.

5. Брек О. О. Стан сполучної тканини та його вплив на результати хірургічного лікування пацієнтів із післяопераційними вентральними грижами / О. О. Брек // Харк. хірург. школа. - 2015. - № 1. - С. 31-35.

6. Дисплазія сполучної тканини, як предиктор виникнення гриж передньої черевної стінки : монографрія / за ред. В. П. Польового, В. В. Власова, В. В. Арсенюка. - Чернівці : Медуніверситет, 2016. - 288 с.

7. Lipid peroxidation and antioxidant status in patients with hernia and stomach cancer/K. Batcioglu, N. Mehmet, I. C. Ozturk [et al.] // Cancer Invest. - 2014. - No. 24 (1). P. 18-21.

8. Cerebral oxidative stress and depression of energy metabolism correlate with severity of diffuse brain

\section{REFERENCES}

1. Bilianskyi, L.S., Todurov, I.M., \& Kosiukhno, S.V. (2015). Khirurhichna taktyka u khvorykh z hihantskymy defektamy cherevnoi stinky [Surgical tactics in patients with giant defects of the abdominal wall]. Ukrainskyi zhurnal khirurhii - The Ukrainian Journal of Surgery, 2 (11), 19-24 [in Ukrainian].

2. Petrov, D.Yu., Kovalev, A.I., \& Smirnov, A.V. (2013). Differentsirovannyy podhod $\mathrm{k}$ vyboru metoda allogernioplastiki [Differentiated approach to the choice of the method of allogeneoplasty]. Proceedings of the Conference: Aktualnye voprosy gerniologii - Actual Questions of Herniology. Moscow [in Russian].

3. Feleshtynskyi, Ya.P. (2016). Suchasni sposoby khirurhichnoho likuvannia pislia operatsiinykh hryzh zhyvota [Modern methods of surgical treatment after operational abdominal hernia]. Zdorovia Ukr. - Health of Ukraine, 24-27 [in Ukrainian].

4. Brek, O.O. (2015). Morfometrychni ta histolohichni zminy tkanyn u khvorykh pislia operatsii z pryvodu pisliaoperatsiinykh hryzh cherevnoi porozhnyny [Morphometric and histological changes of tissues in patients after injury in rats / B. Tavazzi, S. Signoretti, G. Lazzarino [et al.] // Neurosurgery. -2015. - No. 56 (2). - P. 582-589.

9. Chong Z. Z. Oxidative stress in the brain: novel cellular targets that govern survival duringneurodegenerative disease / Z. Z. Chong, F. Li, K. Maiese // Progress in Neurobiology. - 2015. - No. 75 (4). - P. 207.

10. Charlson M. E. The therapeutic efficacy of critical care units from two perspectives: a traditional cohort approach vs a new case-control methodology / M. E. Charlson, F. L. Sax // J. Chronic Dis. - 1987. - No. 40 (1). P. 31-39.

11. Classification of primary and incisional abdominal wall hernias / F. E. Muysoms, M. Miserez, F. Berrevoet [et al.] // Hernia. - 2009. - No. 13 (4). - P. 407-414.

12. Константинова Н. А. Оценка криоглобулинов в сыворотке крови с учетом циркулирующих иммунных комплексов / Н. А. Константинова, А. Ю. Кирсанов // Лаб. дело. - 1989. - № 11. - С. 62-65.

13. Бочков Н. П. Медична генетика; підручник / Н. П. Бочков, А. Ф. Захаров, В. І. Іванов. - М., 1984. C. 180

14. Чевари С. Роль супероксиддисмутазы в окислительных процессах клетки и метод определения ее в биологических материалах / С. Чевари, И. Чаба, Й. Секей // Лаб. дело. - 1985. - № 11. - С. 678-681.

15. Метод определения активности каталазы / М. А. Королюк, Л. И. Иванова, И. Г. Майорова, В. Е. Токарев // Лаб. дело. - 1988. - № 1. - С. 16-19.

16. Андреева Л. И. Модисрикация метода определения перекисей липидов в тесте с тиобарбитуровой кислотой / Л. И. Андреева, Л. А. Кожемякин, А. А. Кишкун // Лаб. дело. - 1988. - № 11. - С. 41-43.

operations for postoperative hernias of the abdominal cavity]. Klinichna khirurhiia - Clinical Surgery, 5, 27-30 [in Ukrainian].

5. Brek, O.O. (2015). Stan spoluchnoi tkanyny ta yoho vplyv na rezultaty khirurhichnoho likuvannia patsiientiv iz pisliaoperatsiinymy ventralnymy hryzhamy [The state of connective tissue and its influence on the results of surgical treatment of patients with postoperative ventral hernias]. Kharkivska khirurhichna shkola-Kharkiv Surgical School, 1, 31-35 [in Ukrainian].

6. Polovyi, V.P., Vlasov, V.V., \&Arseniuk, V.V. (2016). Dysplaziia spoluchnoi tkanyny, yak predyktor vynyknennia hryzh perednoi cherevnoi stinky: monohrafiia [Dysplasia of connective tissue, as a predictor of occurrence of anterior abdominal hernia: monograph]. Chernivtsi: Meduniversytet [in Ukrainian].

7. Batcioglu, K., Mehmet, N., Ozturk, I.C., Yilmaz, M., Aydoglu, N., Ergykan, R., ... \& Karagozleer, A.A. (2014). Lipid peroxidation and antioxidant status in patients with hernia and stomach cancer. Cancer Invest., 24 (1), 18-21. 
8. Tavazzi, B., Signoretti, S., Lazzarino, G., Amorini, A.M., Delfini, R., ... \& Vagnozzi, R. (2015). Cerebral oxidative stress and depression of energy metabolism correlate with severity of diffuse brain injury in rats. Neurosurgery, 56 (2), 582-589.

9. Chong, Z.Z., Li, F., \& Maiese, K. (2015). Oxidative stress in the brain: novel cellular targets that govern survival duringneurodegenerative disease. Progress in Neurobiology, 75 (4), 207.

10. Charlson, M.E., \& Sax, F.L. (1987). The therapeutic efficacy of critical care units from two perspectives: a traditional cohort approach vs a new case-control methodology. J. Chronic Dis., 40 (1), 31-39.

11. Muysoms, F.E., Miserez, M., \& Berrevoet, F., Campanelli, G., Champault, G.G., Chelala, E., ... \& Kingsnorth, A. (2009). Classification of primary and incisional abdominal wall hernias. Hernia, 13 (4), 407-414.

12. Konstantinova, N.A., \& Kirsanov, A.Yu. (1989). Otsenka krioglobulinov $v$ syvorotke krovi s uchetom tsirkuliruyuschikh immunnykh kompleksov [Evaluation of cryoglobulins in serum taking into account circulating immune complexes]. Laboratornoe Delo - Laboratory Work, 11, 62-65 [in Russian].

13. Bochkov, N.P., Zakharov, A.F., \& Ivanov, V.I. (1984). Medychna henetyka. Pidruchnyk [Medical Genetics. Handbook]. Moscow [in Ukrainian].

14. Chevari, S., \& Chaba, I. (1985). Rol superoksiddismutazy $v$ okisnenykh protsesakh kletki i metod opredeleniya ee $v$ biologicheskikh [The role of superoxide dismutase in oxidized cell processes and the method of its determination in biological materials]. Laboratornoye Delo - Laboratory Work, 11, 678-681 [in Russian].

15. Korolyuk, M.A., Ivanova, L.I., Mayorova, I.G., \& Tokarev, V.E. (1988). Metod opredeleniya aktivnosti katalazy [Method of determining the activity of catalase]. Laboratornoe Delo - Laboratory Work, 1, 16-19 [in Russian].

16. Andreeva, L.I., Kozhemyakin, L.A., \& Kishkun, A.A. (1988). Modifikatsiya metoda opredeleniya perekisey lipidov $v$ teste s tiobarbiturovoy kislotoy [Modification of the method for determining lipid peroxides in a test with thiobarbituric acid]. Laboratornoye Delo Laboratory Work, 11, 41-43 [in Russian].

\section{ОСОБЕННОСТИ ПРО- И АНТИОКСИДАНТНОЙ СИСТЕМ И ОБМЕНА СОЕДИНИТЕЛЬНОЙ ТКАНИ У ПАЦИЕНТОВ С ПОСЛЕОПЕРАЦИОННОЙ ВЕНТРАЛЬНОЙ ГРЫЖЕЙ В УСЛОВИЯХ КОМОРБИДНОСТИ}

\section{Резюме}

Вступление. Проблема рецидивов послеоперационных вентральных грыж (ПОВГ) продолжает оставаться одной из актуальных. Использование сетчатых имплантатов в лечении ПОВГ значительно снизило количество осложнений и рецидивов, тем не менее их частота и дальше высокая.

Цель исследования - изучить особенности про- и антиоксидантного статуса и обмена соединительной ткани у пациентов с ПОВГ в условиях коморбидности в зависимости от типа полипропиленовой сетки и в комбинации ее с PRF мембраной.

Методы исследования. Обследовано 276 пациентов с ПОВГ (основная группа и группа сравнения), которые были разделены по типу имплантированной полипропиленовой сетки во время выполнения операционного вмешательства, с целью оценки состояния метаболизма соединительной ткани.

Результаты и обсуждение. Было доказано, что применение “легкой" сетки "Омега-2" в комбинации c PRF мембраной в хирургическом лечении пациентов с ПОВГ в условиях коморбидности лучше способствует улучшению показателей обмена соединительной ткани и прооксидантно-антиоксидантного статуса, чем при использовании “легких" и "тяжелых" сеток

Вывод. Использование в хирургическом лечении больных ПОВГ в условиях коморбидности "легкой" сетки "Омега-2" в комбинации с PRF мембраной способствует лучшей положительной динамике про- и антиоксидантного статуса по исследованным биохимическим показателям, чем при применении "легких" u "тяжелых" сеток (p<0,05), а также приводит к наиболее весомому улучшению показателей метаболизма соединительной ткани по исследованным параметрам $(p<0,05)$ по сравнению с использованием "легких" и "тяжелых" сеток.

КЛЮЧЕВЫЕ СЛОВА: послеоперационные вентральные грыжи; полипропиленовая сетка; PRF мембрана; про- и антиоксидантная системы; дисплазия соединительной ткани. 


\section{FEATURES OF PRO- AND ANTIOXIDANT SYSTEM AND METABOLISM OF FIBROUS TISSUE IN PATIENTS WITH POSTOPERATIVE VENTRAL HERNIA ON THE BACKGROUND OF COMORBIDITY}

\section{Summary}

Introduction. The problem of recurrence of postoperative ventral hernias $(\mathrm{POVH})$ continues to be one of the most urgent. The use of mesh implants in the treatment of POVH significantly reduced the number of complications and relapses, but their frequency remains high.

The aim of the study - to learn the features of pro- and antioxidant status and the exchange of connective tissue in patients with POVH under comorbid conditions, depending on the type of mesh implant.

Research Methods. 276 patients with POVH (main and comparative groups) were examined, who were separated by type of implanted polypropylene mesh during surgical intervention in order to assess the state of connective tissue metabolism.

Results and Discussion. It has been proved that the use of a lightweight mesh Omega-2 in combination with a PRF membrane in the surgical treatment of patients with POVH in conditions of comorbidity better contributes to the improvement of indicators of the exchange of connective tissue and prooxidant-antioxidant status compared to the use of light and heavy mesh.

Conclusion. The use in surgical treatment of patients with POVH in conditions of comorbidity of a lightweight mesh Omega-2 in combination with the PRF membrane, contributes to better positive dynamics of pro- and antioxidant status according to the studied biochemical indices than when using "light" and "heavy" meshes ( $p<0.05)$, and also leads to significant improvement of metabolism indices of connective tissue according to the studied parameters $(p<0.05)$ comparing to the application of "light" and "heavy" meshes.

KEY WORDS: postoperative ventral hernia; polypropylene mesh; PRF membrane; pro- and antioxidant system; dysplasia of the connective tissue.

Адреса для листування: В. І. П'ятночка, Тернопільський державний медичний університет імені І. Я. Горбачевського, майдан Волі, 1, Тернопіль, 46001, Україна, e-mail: pyatnochkait@tdmu.edu.ua 